\title{
Lipid peroxidation in rats treated with vincristine sulphate and nandrolone decanoate
}

\author{
[Peroxidação lipídica em ratos tratados com sulfato de vincristina e
} decanoato de nandrolona]

\author{
D.B. Martins ${ }^{1}$, S.T.A. Lopes ${ }^{2}$, C.M. Mazzanti ${ }^{2}$, R.Spanevello ${ }^{3}$, R. Schmatz ${ }^{4}$, \\ M. Corrêa $a^{4}$, N. Stefanello ${ }^{4}$, M.R. Schetinger ${ }^{4}$, V. Morsch ${ }^{4}$, A.P.M. Veiga ${ }^{3}$ \\ ${ }^{1}$ Programa de Pós-graduação em Medicina Veterinária - UFSM - Santa Maria, RS \\ Avenida Roraima, $\mathrm{n}^{\mathrm{0}} 1000$. \\ Centro de Ciências Rurais (CCR/UFSM), \\ 97105-900 - Santa Maria, RS. \\ ${ }^{2}$ Departamento de Clínica de Pequenos Animais - UFSM - Santa Maria, RS \\ ${ }^{3}$ Universidade Federal do Rio Grande do Sul - UFRGS - Porto Alegre, RS \\ ${ }^{4}$ Departamento de Química - UFSM - Santa Maria, RS
}

\begin{abstract}
Brain and serum lipid peroxidation was studied in rats treated with vincristine sulphate and different doses of nandrolone decanoate. Thirty rats were distributed into six groups $(n=5)$. The treatments were applied once a week for two weeks. Sample collection was performed in the third week. Treatments during the first week were: G1 (control) - physiologic solution, G2- vincristine sulphate $\left(4 \mathrm{mg} / \mathrm{m}^{2}\right)$, G3physiologic solution, G4- physiologic solution, G5- vincristine sulphate $\left(4 \mathrm{mg} / \mathrm{m}^{2}\right)$, and G6- vincristine sulphate $\left(4 \mathrm{mg} / \mathrm{m}^{2}\right)$. In the second week, they were: $\mathrm{G} 1$ (control) - physiologic solution, G2- physiologic solution, G3- nandrolone decanoate $\left(1.8 \mathrm{mg} / \mathrm{kg}^{-1}\right)$, G4- nandrolone decanoate $\left(10 \mathrm{mg} / \mathrm{kg}^{-1}\right)$, G5nandrolone decanoate $\left(1.8 \mathrm{mg} / \mathrm{kg}^{-1}\right)$, and G6- nandrolone decanoate $\left(10 \mathrm{mg} / \mathrm{kg}^{-1}\right)$. Lipid peroxidation increased with the isolated use of vincristine and nandrolone decanoate, and with vincristine associated to the highest dose of the ester as well. These results suggest that vincristine sulphate and nandrolone decanoate increase free radical production. Therapeutic dose of nandrolone decanoate when associated with vincristine sulphate proved to be beneficial, as it was able to protect the organism from damaging processes involved in free radical production.
\end{abstract}

Keywords: rat, anabolic androgenic steroid, chemotherapeutic, free radicals, brain, blood serum

\section{RESUMO}

Este estudo teve por objetivo detectar a peroxidação lipídica presente no cérebro e no soro de ratos tratados com sulfato de vincristina e diferentes doses de decanoato de nandrolona. Trinta ratos foram distribuídos em seis grupos ( $n=5)$. Os tratamentos foram aplicados uma vez por semana, durante duas semanas, e a coleta de amostras foi realizada na terceira semana. Na primeira semana, os tratamentos consistiram de: G1(controle) - solução fisiológica; G2 - sulfato de vincristina $\left(4 \mathrm{mg} / \mathrm{m}^{2}\right)$; $G 3$ - solução fisiológica; $G 4$ - solução fisiológica; G5 - sulfato de vincristina $\left(4 \mathrm{mg} / \mathrm{m}^{2}\right)$ e G6 - sulfato de vincristina $\left(4 \mathrm{mg} / \mathrm{m}^{2}\right)$. Na segunda semana: G1(controle) - solução fisiológica; G2 - solução fisiológica; G3 - decanoato de nandrolona (1.8mg/ $\left.\mathrm{kg}^{-1}\right)$; G4 - decanoato de nandrolona (10mg/ $\left.\mathrm{kg}^{-1}\right)$; G5 - decanoato de nandrolona $\left(1.8 \mathrm{mg} / \mathrm{kg}^{-1}\right)$ e G6 - decanoato de nandrolona $\left(10 \mathrm{mg} / \mathrm{kg}^{-1}\right)$. A peroxidação lipídica aumentou com o uso isolado tanto da vincristina quanto do decanoato de nandrolona e com a associação da vincristina à dose mais alta do éster. Estes resultados sugerem que o sulfato de vincristina e o decanoato de nandrolona aumentam a produção de radicais livres. A dose terapêutica do decanoato de nandrolona, quando associada ao sulfato de vincristina, provou ser benéfica, já que foi capaz de proteger o organismo dos processos prejudiciais induzidos pela produção de radicais livres.

Palavras-chave: rato, esteroide anabólico androgênico, quimioterápico, radicais livres, cérebro, soro sanguíneo

Recebido em 6 de julho de 2009

Aceito em 6 de dezembro de 2010

E-mail:vetdanielimartins@yahoo.com.br 


\section{INTRODUCTION}

Chemotherapy is one of the most important tools for the treatment of neoplastic diseases (McKnight, 2003). The first report of chemotherapy used in Veterinary Medicine dates from 1960 (McClelland, 1963). Nowadays, various agents have been used in clinical practice and others are subjects of research (Norris and Withrow, 1984; Rodaski and Nardi, 2003). These agents have the purpose of prolonging survival and improving the quality of life in patients with cancer (McKnight, 2003).

Vincristine sulphate is among the most used agents in small animal clinical oncology (Cave et al., 2007). Its application has been reported in illness such as canine transmissible venereal tumor (CTVT) (Rogers et al., 1998; Nak et al., 2005), lymphomas (Poncé et al., 2004; Rodaski e Nardi, 2006), leukemia (Rodaski and Nardi, 2006) and kidney nephroblastoma (Seaman and Patton, 2003).

Selection of the drug treatment must be considered for each patient and is a critical point for the outcome of the antitumor therapy (McKnight, 2003). Vincristine used alone as a chemotherapeutic agent is able to induce a total remission of CTVT in most cases (Nak et al., 2005; Rodaski and Nardi, 2006), while in certain types of sarcoma its use must be combined with other drugs for a satisfactory therapeutic response (Cave et al., 2007).

Adverse effects of vincristine include nonselective cytotoxicity that results in moderate myelosuppression (both erythrocytes and leukocytes), anorexia, intestinal disturbances, alopecia (Nak et al., 2005), necrosis (tissue extravasation) (Villalobos, 2006), peripheral and rarely central toxicity (Whittaker et al., 1973; Hamilton et al., 1991; Cuddon, 2002). If the professional is familiarized with the agent to be applied, its toxicity can be identified and treated early, improving the wellbeing of the animal (Norris and Withrow, 1984; McKnight, 2003).

Nandrolone decanoate is an anabolic-androgenic steroid (AAS) derived from testosterone and is widely used in medical clinical practice. It is indicated to revert cachexia of patients with cancer and other chronic diseases (Basaria et al., 2001; Morley et al., 2006). It also stimulates bone marrow to produce new blood cells (Saitoh et al., 1999; Bagchus et al., 2005), mainly in cases in which chemotherapy based on vincristine suppresses the bone marrow (Perez et al., 2005). It triggers an increase of erythropoietin production and acts directly on bone marrow hematopoietic progenitors (Saitoh et al., 1999).

Lipid peroxidation is considered an important physiopathologic event in toxicity from antineoplastic drugs as well as from AAS in a number of diseases and also in ischemic and traumatic damage (Braughler et al., 1987). The plasma membrane is one of the most reached places by this biochemical reaction, which leads to changes in its structure and permeability. For this reason, there is lack of selectivity in the ion exchange, organelle content releasing, and production of cytotoxic substances such as malondialdehyde/thiobarbituric acid reactive substances (MDA/TBARS), which cause cell death (Ferreira et al., 1997). The central nervous system (CNS) substantially consists of membranes and fatty acids, which increase the vulnerability of lipid membrane components to oxidative damage and the direct action of free radicals (Vedder et al., 1999).

As vincristine sulphate is a chemotherapeutic agent widely used in small animal clinical oncology and nandrolone decanoate has been used in association to decrease some of its bone marrow cytotoxicity (Perez et al., 2005), the present study aimed to verify brain and serum lipid peroxidation from healthy rats treated with vincristine sulphate and different doses of nandrolone decanoate. The relevance of the present study lies in the lack of information on the effects of the combined or isolated use of vincristine sulphate and nandrolone decanoate on the lipid peroxidation.

\section{MATERIALS AND METHODS}

Thirty adult male Wistar rats from a Central Bioterium, weighing from 260 to 360 grams, were used. The animals were submitted to an adaptation period of 14 days with a solid and liquid diet given ad libitum. The animals were randomly separated into six groups of five animals each. The treatments were applied once weekly during two weeks. Sample collection was carried on during the third week. During the first 
week, the groups received the following treatment: G1 (control) - physiologic solution, G2 - vincristine sulphate $\left(4 \mathrm{mg} / \mathrm{m}^{2}\right), \mathrm{G} 3$ physiologic solution, G4 - physiologic solution, G5 - vincristine sulphate $\left(4 \mathrm{mg} / \mathrm{m}^{2}\right)$, and G6vincristine sulphate $\left(4 \mathrm{mg} / \mathrm{m}^{2}\right)$. During the second week, the treatment consisted of: G1 (control) physiologic solution, G2 - physiologic solution, G3 - nandrolone decanoate $\left(1.8 \mathrm{mg} / \mathrm{kg}^{-1}\right), \mathrm{G} 4$ nandrolone decanoate $\left(10 \mathrm{mg} / \mathrm{kg}^{-1}\right)$, G5 nandrolone decanoate $\left(1.8 \mathrm{mg} / \mathrm{kg}^{-1}\right)$, and G6 nandrolone decanoate $\left(10 \mathrm{mg} / \mathrm{kg}^{-1}\right)$.

The dose of vincristine was based on a previous publication (Perez et al., 2005). Nandrolone decanoate was used at the therapeutic dose $\left(1.8 \mathrm{mg} / \mathrm{kg}^{-1}\right.$ weekly) currently used for small animals (Nelson and Couto, 2006) and at an overdose $\left(10 \mathrm{mg} / \mathrm{kg}^{-1}\right)$. Vincristine was applied through intraperitoneal injection.

Nandrolone decanoate was diluted in a vegetalsource fat vehicle (olive oil) previously tested and shown to be neutral and, thus, adequate for deep intramuscular injection (IM). The hind limb of all animals was tricotomized in order to observe any possible reaction to the ester.

After the treatment, the animals were fasted for a 12-hour period and submitted to euthanasia in a bell glass with ethyl ether. Blood collection was performed through heart puncture. One half of the collected blood was drawn into tubes free of anticoagulants, while the other half was drawn into tubes containing ethilene diamine tetraacetic acid. Brain structures were separated into cerebellum, cerebral cortex, striatum, and hippocampus, and homogenized separately in Medium I and centrifuged at 1,800 rpm for 10 minutes. Serum was separated for lipid peroxidation evaluation. Total blood was homogenized in PBS $0.1 \mathrm{M}(\mathrm{pH} 7.4)$ containing Triton $\mathrm{X}-100(0.03 \%)$ and stocked at $-20^{\circ} \mathrm{C}$ for further enzymatic assays.

TBARS reactions were determined by the method previously described (Jentzsch et al., 1996) for the different parts of the brain, and values were expressed in nmol $\mathrm{MDA} / \mathrm{mg}$ of protein. The same technique (Jentzsch et al., 1996) was employed for blood serum, except that the results were expressed in $\mathrm{nmol} \mathrm{MDA} / \mathrm{mL}$.

One-way ANOVA followed by Duncan's new multiple range test was used for statistical analysis $(\mathrm{P}<0.05)$. Results were expressed by mean \pm standard error of measurement.

This study was approved by the Animal Research Ethics Committee at the Universidade Federal de Santa Maria, Santa Maria, RS, under protocol number UFSM-RS 23081.000780/200715.

\section{RESULTS AND DISCUSSION}

The results obtained in this study are shown in Figures 1 and 2 for brain and blood serum TBARS, respectively.

A significant increase in TBARS $(\mathrm{P}<0.05)$ was detected in all cerebral structures that were analyzed. An increase in TBARS was observed in $\mathrm{G} 2$ and $\mathrm{G} 4(\mathrm{P}<0.01)$ and $\mathrm{G} 3(\mathrm{P}<0.05)$ in striatum. The cerebral cortex and hippocampus showed very similar behaviors, showing an increase $(\mathrm{P}<0.05)$ in TBARS levels in $\mathrm{G} 3, \mathrm{G} 4$, and G6. In cerebellum, there was only a change in G6. Serum TBARS levels were altered in G2 and G3 $(\mathrm{P}<0.05)$ and G6 $(\mathrm{P}<0.01)$ as compared to the control group.

The increased TBARS values may be due in part to not only the aerobic metabolism of the CNS, but also to high levels of polyunsaturated fatty acids and low levels of antioxidant defenses (Wajner et al., 2004). The results in striatum demonstrate that the separate use of the two drugs increased free radical production at that site. However, their final products were the same as those of the control group when they were used in association (G5). Although vincristine does not show a good penetration in the CNS (Rodaski and Nardi, 2006), the dose used in this study was enough to cause lipid peroxidation in striatum. 

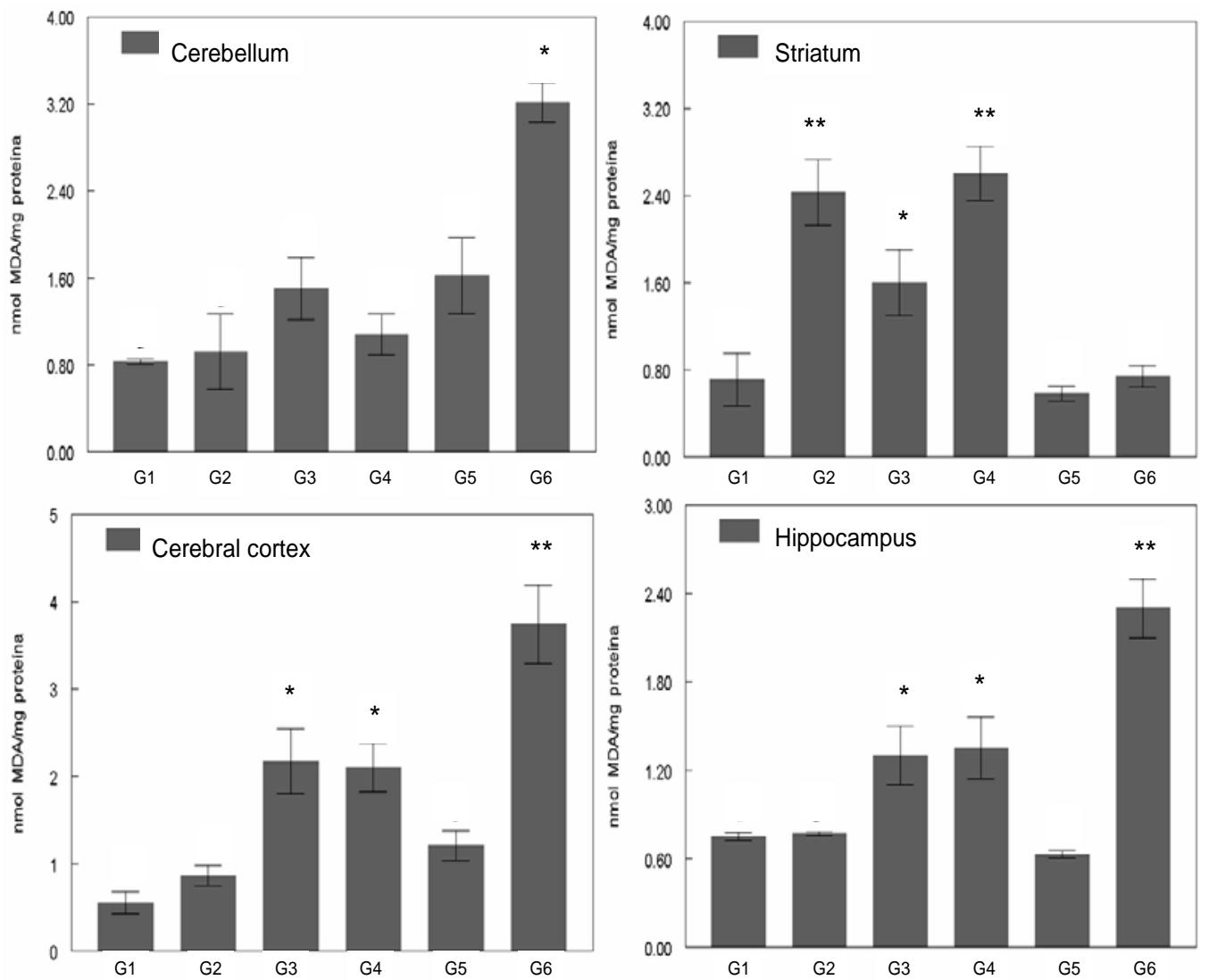

Figure 1. Mean values of thiobarbituric acid reactive substances (TBARS) for the evaluation of brain tissue (cerebellum, striatum, cerebral cortex, and hippocampus) of rats submitted to different treatments: G1 (control), G2 (vincristine $-4 \mathrm{mg} / \mathrm{m}^{2}$ ), G3 (nandrolone decanoate - $1.8 \mathrm{mg} / \mathrm{kg}^{-1}$ ), G4 (nandrolone decanoate - $10 \mathrm{mg} / \mathrm{kg}^{-1}$ ), G5 (vincristine - $4 \mathrm{mg} / \mathrm{m}^{2}$ plus nandrolone decanoate - $1.8 \mathrm{mg} / \mathrm{kg}^{-1}$ ), and G6 (vincristine - $4 \mathrm{mg} / \mathrm{m}^{2}$ plus nandrolone decanoate $-10 \mathrm{mg} / \mathrm{kg}^{-1}$ ). Bars represent mean $\pm \mathrm{SEM} ;\left(^{*}\right)$ indicates a significant difference at $\mathrm{P}<0.05$; $(* *)$ indicates a significant difference at $\mathrm{P}<0.01 ;(\mathrm{n}=5)$.



Figure 2. Mean values of thiobarbituric acid reactive substances (TBARS) for the evaluation of blood serum of rats submitted to different treatments: G1 (control), G2 (vincristine - 4mg/ $\mathrm{m}^{2}$ ), G3 (nandrolone decanoate $1.8 \mathrm{mg} / \mathrm{kg}^{-1}$ ), G4 (nandrolone decanoate - $10 \mathrm{mg} / \mathrm{kg}^{-1}$ ), G5 (vincristine $-4 \mathrm{mg} / \mathrm{m}^{2}$ plus nandrolone decanoate $1.8 \mathrm{mg} / \mathrm{kg}^{-1}$ ), and G6 (vincristine $-4 \mathrm{mg} / \mathrm{m}^{2}$ plus nandrolone decanoate - $10 \mathrm{mg} / \mathrm{kg}^{-1}$ ). Bars represent mean $\pm \mathrm{SEM}$; $\left(^{*}\right)$ indicates a significant difference at $\mathrm{P}<0.05 ;(* *)$ indicates a significant difference at $\mathrm{P}<0.01 ;(\mathrm{n}=5)$. 
It is well known that the increase of reactive oxygen species (ROS) may lead to a higher blood-brain barrier permeability and thus inhibit mitochondrial respiration and increase protein oxidation (Gilman et al., 1993; Rovere et al., 1995), impairing synaptic interactions. The isolated use of nandrolone decanoate also increased lipid peroxidation. The value presented by G4 may the higher dose or even because of the variable amount of androgenic receptors in different types of non-reproductive tissue cells, such as in the brain (Manolagas and Kousteni, 2001).

In cerebral cortex and hippocampus, the isolated use of both doses of nandrolone decanoate augmented free radical production. The results obtained show that lipid peroxidation was significantly higher in G6 than in the other groups, making the potentialization of nandrolone decanoate action by vincristine evident in those parts of the brain. In another study, no in vitro effect of testosterone or its derivative substances on TBARS levels was detected in different CNS cells (Vedder et al., 1999). Thus, the need for both in vivo studies and experiments using an association with other drugs are relevant since the type of response may undergo changes in such a case.

In addition, none of the drugs used alone caused an increase in ROS in cerebellum. However, the use of vincristine in association with an overdose of AAS stimulated lipid peroxidation. In a similar fashion, the isolated use of certain hormones such as testosterone showed no effect on the oxidative status in rat prostate, although in association with other substances it induced a marked increase in oxidative stress as well as an inhibition of enzymatic antioxidant activity in the same site, which could lead to carcinogenesis (Tam et al., 2003).

The isolated employment of the drugs in this experiment caused a rise in serum MDA production. This effect was reinforced by the behavior of G6, which was significantly higher than G2 and G3. Published results of in vitro studies (Benchekroun and Robert, 1992) using tumor cell cultures and cytotoxic doses of vincristine found no traces of lipid peroxidation. However, the present experiment demonstrated free radical production in brain tissue (striatum) and in blood serum, showing that the in vivo interaction of various components with vincristine is determinant for the obtained results. Lipid peroxidation caused by the chemotherapeutic agent could collaborate in neoplastic cell apoptosis, decreasing its viability. In this sense, further studies are necessary.

Interestingly, the pharmacological combination used in G5 presented similar physiological values to those of G1 not only in serum TBARS but also in all the studied brain structures studied. Thus, the data show that the association between the used therapeutic dose of nandrolone decanoate and vincristine is capable of neutralizing the free radical production induced by their isolated use both in brain and blood serum. Another paper (Guzmán et al., 2005) showed a similar antitumoral effect caused by testosterone in rat brain. Ex-vivo studies have also found this hormone to protect cerebellum cells in cell cultures induced to death by oxidative stress (Ahlbom et al., 2001).

In conclusion, lipid peroxidation increased as a result of the isolated use of both tested drugs and also as a result of the association between the chemotherapeutic agent and an overdose of AAS. The association between the therapeutic dose of nandrolone decanoate and vincristine was able to neutralize the free radical production induced by their isolated use in brain and blood serum. Although vincristine is not able to totally penetrate the blood-brain barrier, it is possible to state that the dose used in G2 was sufficient to produce free radicals in the brain. The serum TBARS results presented in this study are similar to those exhibited by brain tissue, being possible to use it in domestic animals.

\section{ACKNOWLEDGEMENTS}

This research was supported by the Coordenação de Aperfeiçoamento de Pessoal de Nível Superior (CAPES).

\section{REFERENCES}

AHLBOM, E.; PRINS, G.S.; CECCATELLI, S. Testosterone protects cerebellar granule cells from oxidative stress-induced cell death through a receptor mediated mechanism. Brain Res., v.892, p.255-262, 2001. 
BAGCHUS, W.M.; SMEETS, J.M.W.; VERHEUL, H.A.M. et al. Pharmacokinetic evaluation of three different intramuscular doses of nandrolone decanoate: analysis of serum and urine samples in healthy men. J. Clin. Endocrinol. Metab., v.90, p.2624-2630, 2005.

BASARIA, S.; WAHLSTROM, J.T.; DOBS, A.S. Anabolic-androgenic steroid therapy in the treatment of chronic diseases. J. Clin. Endocrinol. Metab., v.86, p.5108-5117, 2001.

BENCHEKROUN, M.N.; ROBERT, J. Measurement of doxorubicin-induced lipid peroxidation under the conditions that determine cytotoxicity in cultured tumor cells. Anal Biochem., v.201, p.326-330, 1992.

BRAUGHLER, J.M.; PREGENZER, J.F.; CHASE, R.L. et al. Novel 21-amino steroids as potent inhibitors of iron-dependent lipid peroxidation. J. Biol. Chem., v.262, p.1043810440, 1987.

CAVE, T.A.; NORMAN, P.; MELLOR, D. Cytotoxic drug use in treatment of dogs and cats with cancer by UK veterinary practices (2003 to 2004). J. Small Anim. Pract., v.48, p.371-377, 2007.

CUDDON, P.A. Acquired canine peripheral neuropathies. Vet. Clin. N. Am.: Small Anim. Pract., v.32, p.207-249, 2002.

FERREIRA, A.L.A.; MATSUBARA, L.S. Radicais livres: conceitos, doenças relacionadas, sistema de defesa e estresse oxidativo. Rev. Assoc. Med. Bras., v.43, p.61-68, 1997.

GILMAN, S.C.; BONNER, M.J.; PELLMAR, T.C. Effect of oxidative stress on excitatory amino acid release by cerebral cortical synaptosomes. Free Radic. Biol. Med., v.15, p.671-675, 1993.

GUZMÁN, D.C.; MEJIA, G.B.; VÁSQUEZ, I.E. et al. Effect of testosterone and steroids homologues on indolamines and lipid peroxidation in rat brain. J. Steroid Biochem. Mol. Biol., v.94, p.369-373, 2005.

HAMILTON, T.A.; COOK, J.R.; BRAUND, K.G. et al. Vincristine-induced peripheral neuropathy in a dog. J. Am. Vet. Med. Assoc., v.1984, p.635-638, 1991.
JENTZSCH, A.M.; BACHMANN, H.; FÜRST, P. et al. Improved analysis of malondialdehyde in human body fluids. Free Radic. Biol. Med., v.20, p.251-256, 1996.

MANOLAGAS, S.C.; KOUSTENI, S. Perspective: nonreproductive sites of action of reproductive hormones. Endocrinology, v.142, p.2200-2204, 2001.

McCLELLAND, R.B. Cyclophosphamide therapy in lymphoma of the dog. Cornell Vet., v.53, p.319-322, 1963.

McKNIGHT, J.A. Principles of chemotherapy. Clin. Tech. Small Anim. Pract., v.18, p.67-72, 2003.

MORLEY, J.E.; THOMAS, D.R.; WILSON, M.M.G. Cachexia: pathophisiology and clinical relevance. Am. J. Clin. Nutr., v.83, p.735-743, 2006.

NAK, D.; NAK, Y.; CANGUL, I.T. et al. A clinical-pathological study on the effect of vincristine on transmissible venereal tumour in dogs. J. Vet. Med., v.52, p.366-370, 2005.

NELSON, R.W.; COUTO, C.G. Distúrbios da micção. In: NELSON, R.W.; COUTO, C.G. (Eds). Medicina Interna de Pequenos Animais. 3.ed. Rio de Janeiro: Elsevier, 2006. p.625-633.

NORRIS, A.M.; WITHROW, S.J. A review of cancer chemotherapy for pet animals. Can. Vet. J., v.25, p.153-157, 1984.

PEREZ, R.R.; SILVA, M.A.M.L.; VARZIM, F.L.S.B. et al. A ação do decanoato de nandrolona (Deca Durabolin) sobre parâmetros hematológicos e proteína total plasmática de ratos (Rattus rattus) com depressão medular induzida após administração de sulfato de vincristina (Oncovin). Cienc. Rural, v.35, p.589595, 2005.

PONCÉ, F.; MAGNOL, J.P.; LEDIEU, D. et al. Prognostic significance of morphological subtypes in canine malignant lymphomas during chemotherapy. J. Small Anim. Pract., v.167, p.158-166, 2004.

RODASKI, S.; NARDI, A.B. Quimioterapia antineoplásica em cães e gatos. 2.ed. Curitiba: Bio Editora, 2006. 308p. 
ROGERS, K.S.; WALKER, M.A.; DILLON, H.B. Transmissible venereal tumor: a retrospective study of 29 cases. J. Am. Anim. Hosp. Assoc., v.34, p.463-470, 1998.

ROVERE, D.F.; GRANTA, A.; BROCCIO, M. et al. Hemoglobin oxidative stress in cancer. Anticancer Res., v.15, p.2089-2095, 1995.

SAITOH, T.; MORIMOTO, K.; KUMAGAI, T. et al. Comparision of erythropoietic response to androgen in young and old senescence accelerated rats. Mech. Ageing Dev., v.109, p.125-139, 1999.

SEAMAN, R.L.; PATTON, C.S. Treatment of renal nephroblastoma in an adult dog. J. Am. Anim. Hosp. Assoc., v.39, p.76-79, 2003.

TAM, N.N.; GHATAK, S.; HO, S.M. Sex hormone-induced alterations in the activities of antioxidant enzymes and lipid peroxidation status in the prostate of Noble rats. Prostate, v.55, p.1-8, 2003.
VEDDER, H.; ANTHES, N.; STUMM, G. et al. Estrogen hormones reduce lipid peroxidation in cells and tissues of the central nervous system. $J$. Neurochem., v.72, p.2531-2538, 1999.

VILLALOBOS, A. Dealing with chemotherapy extravasations: a new technique. J. Am. Anim. Hosp. Assoc., v.42, p.321-325, 2006.

WAJNER, M.; LATINI, A.; WYSE, A.T.S. et al. The role of oxidative damage in the neuropathology of organic acidurias: insights from animal studies. J. Inherit. Metab. Dis., v.27, p.427-448, 2004.

WHITTAKER, J.A.; PARRY, D.H.; BUNCH, C. et al. Coma associated with vincristine therapy. Br. Med. J., v.4, p.335-337, 1973. 